\title{
CATASTROPHE BOND SEBAGAI INSTRUMEN PEMBIAYAAN PEMERINTAH DALAM PENANGGULANGAN BENCANA ALAM DI INDONESIA
}

\author{
Amardianto Arham \\ Amrie Firmansyah \\ Politeknik Keuangan Negara STAN \\ Alamat Korespondensi: amrie.firmansyah@gmail.com
}

\begin{abstract}
The frequent occurrence of natural disasters in Indonesia makes the government need a lot of money when it is overcome. In order to not fully burden the budget, the government needs new sources of funding. This study aims to analyze the plan to issue the catastrophe bond as a government financing instrument for natural disaster management. This study uses a qualitative method by focusing on the literature review. The results show that a catastrophe bond can be used as an instrument of government financing in natural disaster management in Indonesia. However, the implementation of the plan to issue the catastrophe bond still requires a law that explicitly regulates the procedures for its implementation. In addition, the government needs to conduct an in-depth study to establish an institution as an issuer of the catastrophe bond and makes its law.
\end{abstract}

\section{KATA KUNCI:}

Catastrophe Bond, Keuangan Publik, Kebijakan Publik.

\begin{abstract}
ABSTRAK
Seringnya terjadi bencana alam di Indonesia membuat pemerintah membutuhkan biaya yang tidak sedikit saat penanggulangan. Agar tidak sepenuhnya membebani anggaran, pemerintah membutuhkan sumber pendanaan baru. Penelitian ini bertujuan untuk menganalisis rencana penerbitan catastrophe bond sebagai instrumen pembiayaan pemerintah untuk penanggulangan bencana alam. Penelitian ini menggunakan metode kualitatif dengan berfokus pada telaah pustaka. Hasil penelitian menunjukkan bahwa catastrophe bond dapat dijadikan sebagai instrumen pembiayaan pemerintah dalam penanggulangan bencana alam di Indonesia. Namun demikian, implementasi rencana penerbitan catastrophe bond tersebut masih membutuhkan payung hukum yang secara eksplisit mengatur tata cara pelaksanaanya. Selain itu, pemerintah perlu melakukan kajian yang mendalam untuk menetapkan lembaga penerbit catastrophe bond serta membuat payung hukumnya.
\end{abstract}

\section{KLASIFIKASI JEL:}

E62

\section{CARA MENGUTIP:}

Arham, A. \& Firmansyah, A. (2019). Catastrophe bond sebagai instrumen pembiayaan pemerintah dalam penanggulangan bencana alam di Indonesia. Indonesian Treasury Review: Jurnal Perbendaharaan, Keuangan Negara dan Kebijakan Publik, $4(4), 339-349$. 


\section{PENDAHULUAN}

\subsection{Latar Belakang}

Kondisi geografis Indonesia berada di titik pertemuan dua patahan tektonik dan lingkaran vulkanik serta diapit oleh dua samudera besar yang menyebabkan negara ini sangat rentan terpapar risiko bencana alam (http://harian.analisadaily.com). Menurut Bank Dunia, Indonesia termasuk dalam 35 negara di dunia yang memiliki risiko tinggi akan terjadinya korban jiwa dan kerugian ekonomi akibat dampak dari berbagai jenis bencana alam. Hampir seluruh wilayah di Indonesia terpapar risiko atas sembilan bencana alam utama, yaitu gempa bumi, tsunami, banjir, tanah longsor, letusan gunung api, kebakaran hutan, cuaca ekstrim, gelombang ekstrim dan kekeringan. Beberapa kejadian bencana alam seperti gempa bumi dan tsunami di Aceh dan Sumatera bagian utara pada tahun 2004 serta rentetan tiga bencana besar yang terjadi di Indonesia pada tahun 2018 (gempa di Lombok, gempa dan tsunami di Palu dan Donggala, serta tsunami di Selat Sunda) memberikan gambaran dan fakta yang jelas betapa rentannya negeri ini terhadap bencana alam (https://fiskal.kemenkeu.go.id).

Rentannya Indonesia terpapar risiko bencana alam membuat pemerintah perlu memiliki tingkat kesiapan yang jauh lebih baik dalam menghadapi setiap kemungkinan ketidakramahan alam yang berujung pada kerugian materiil. Sejarah kejadian bencana alam di Indonesia menunjukkan besarnya potensi korban jiwa, kerusakan fisik, dan kerugian ekonomi. Menurut data Kementerian Keuangan, antara tahun 2000 sampai dengan tahun 2016, rata-rata kerugian ekonomi langsung berupa rusaknya bangunan dan bukan bangunan akibat bencana alam yang terjadi di Indonesia setiap tahunnya diperkirakan sekitar Rp22,8 triliun (https://fiskal.kemenkeu.go.id).

Berdasarkan Undang-Undang Nomor 24 Tahun 2007 tentang Penanggulangan Bencana menyatakan bahwa alokasi dana penanggulangan bencana bersumber dari pemerintah pusat dan pemerintah daerah. Lebih lanjut, Peraturan Pemerintah Nomor 22 Tahun 2008 tentang Pendanaan dan Pengelolaan Bantuan Bencana menyatakan bahwa sumber pendanaan penanggulangan bencana berasal dari Anggaran Pendapatan dan Belanja Negara (APBN), Anggaran Pendapatan dan Belanja Daerah (APBD), dan/atau masyarakat. Dalam penanggulangan bencana, pemerintah menyediakan dana kontinjensi atau dana cadangan untuk kegiatan kesiapsiagaan pada tahap prabencana, dana siap pakai (on call) yang ditempatkan dalam anggaran Badan Nasional Penanggulangan Bencana (BNPB) untuk kegiatan pada saat tanggap darurat, serta dana bantuan sosial berpola hibah pada tahap pasca bencana. Akan tetapi, kemampuan pemerintah dalam menyediakan pembiayaan untuk bencana dengan dampak yang besar cenderung terbatas. Dana alokasi penanggulangan bencana alam yang bersumber dari APBN relatif lebih kecil dibandingkan dengan kerugian yang dialami. Sebagai contoh, gempa bumi dan tsunami di Aceh pada tahun 2004 memiliki alokasi APBN sebesar Rp 3,3 triliun sedangkan total kerugian mencapai Rp 41,4 triliun atau hanya sebesar 7,9 persen dari total kerugian. Bencana gempa bumi di Yogyakarta pada tahun 2006 yang mengakibatkan kerugian negara sebesar Rp 26,1 triliun hanya memiliki alokasi APBN sebesar 1,1 persen dari total kebutuhan atau sekitar Rp 2,9 triliun (Carolina, 2018). Hal yang sama juga ditemukan pada alokasi dana penanggulangan bencana dalam APBD. Berdasarkan Rencana Nasional Penanggulangan Bencana Nasional 2015-2019, alokasi dana siap pakai dalam APBD hanya rata-rata mencapai 0,1 persen. Setiap tahunnya, pemerintah rata-rata menyediakan dana cadangan bencana sebesar Rp3,1 triliun (https://fiskal.kemenkeu.go.id). Sementara itu, besarnya kerugian dan pendanaan yang terkuras akibat bencana pada rentang 20042013 mencapai Rp126,7 triliun (http://harian.analisadaily.com). Hal tersebut menunjukkan adanya kesenjangan yang tinggi antara besarnya dana yang disediakan dengan besarnya biaya yang harus dikeluarkan, sehingga menyebabkan Indonesia terpapar risiko fiskal yang tinggi akibat bencana alam.

Untuk menghadapi kelemahan penanggulangan bencana terutama mengurangi risiko bencana dan meningkatkan ketangguhan pemerintah dalam menghadapi bencana, pemerintah memerlukan kerangka pembiayaan risiko bencana yang inovatif untuk memenuhi kebutuhan anggaran pendanaan penanggulangan bencana alam dalam jumlah besar (Carolina, 2018). Pemerintah dapat menggunakan instrumen pembiayaan kontinjensi sebagai komplementer APBN dalam menanggung risiko bencana dengan dampak kerugian sedang sampai dengan tinggi (https://fiskal.kemenkeu.go.id). Berdasarkan Undang-Undang Nomor 17 Tahun 2003 tentang Keuangan Negara, sumber-sumber pembiayaan ditetapkan dalam undang-undang tentang APBN untuk menutupi defisit anggaran. Sejak tahun 2009, angka defisit APBN mencapai lebih dari Rp 100 triliun dan cenderung meningkat dari tahun ke tahun (data-apbn.kemenkeu.go.id). Pada tahun 2019, APBN mengalami defisit sebesar Rp296 triliun dan menggunakan pembiayaan anggaran yang berasal dari pembiayaan utang baik berupa Surat Berharga Negara (SBN) atau Surat Utang Negara (SUN) dan Surat Berharga Syariah Negara (kemenkeu.go.id). Berdasarkan Undang Undang Nomor 24 Tahun 2002, SUN terdiri atas Surat 
Perbendaharaan Negara (jangka waktu sampai dengan dua belas bulan) dan Obligasi Negara (jangka waktu lebih dari dua belas bulan). Setelah Indonesia mengalami dua bencana alam besar dengan jarak yang berdekatan, pemerintah Indonesia sedang mengkaji penebitan surat utang bencana alam atau catastrophe bond (https://www.beritasatu.com). Pemerintah membuka opsi untuk menerbitkan surat utang bencana alam (catastrophe bond) layaknya surat utang negara yang selama ini telah lazim dirilis (http://harian.analisadaily.com). Pada 9 Oktober 2018, Menteri Keuangan menyatakan bahwa pemerintah sedang mendalami skema penerbitan catastrophe bond dan menjadi salah satu tema diskusi dalam pertemuan tahunan IMF-World Bank (http://www.merdeka.com). Catastrophe bond merupakan sesuatu yang baru di Indonesia dan sampai saat ini belum pernah ada entitas lokal yang menerbitkan catastrophe bond sebagai instrumen keuangan dan manajemen risiko (https://www.beritasatu.com).

Catastrophe bond sukses diterbitkan untuk pertama kalinya oleh perusahaan Hannover Re pada tahun 1994 (Laster, 2001). Pada tahun 2006, Mexico menjadi negara pertama di dunia yang menggunakan catastrophe bond untuk melindungi kewajiban fiskal terkait bencana alam (MichelKerjan, 2011). Pada tahun 2014, negara-negara di Kepulauan Karibia menerbitkan catastrophe bond untuk penanggulangan bencana angin topan dan gempa bumi (https://worldbank.org). Selanjutnya pada tahun 2016, beberapa negara di kawasan Pasifik (Chili, Kolombia, Mexico, dan Peru) memutuskan untuk menggunakan catastrophe bond untuk memperluas opsi pembiayaan risiko gempa bumi (https://treasury.worldbank.org).

Penelitian terdahulu mengenai analisis rencana penerbitan catastrophe bond di Indonesia masih sangat kurang. Shang, et. al. (2009) mengulas tentang analisis empiris atas penentuan harga catastrophe bond di Indonesia dan menunjukkan pengaruh parameter berdasarkan comonotonicity theory dan jump-diffusion process terhadap harga catastrophe bond. Selain itu, Gunardi \& Setiawan (2015) juga membahas penilaian catastrophe bond secara khusus untuk bencana alam gempa bumi di Indonesia dengan menggunakan distribusi Generalized Extreme Value (GEV) dan model tingkat bunga Cox-Ingersoll-Ross (CIR). Sementara itu, Matucci (2016) mengulas mengenai solusi penggunaan catastrophe bond sebagai sarana pembangunan ekonomi di negara berkembang seperti Indonesia. Matucci (2016) menganalisis rencana penerbitan catastrophe bond di Indonesia mengacu pada perbandingan kondisi catastrophe incsurance market antara Indonesia dengan Mexico. Penelitian-penelitian terdahulu tersebut hanya membahas mekanisme penentuan harga catastrophe bond dan kemungkinan implementasi di Indonesia berdasarkan kondisi sektor privat. Sampai saat ini, belum ada penelitian yang membahas kemungkinan implementasi penggunaan catastrophe bond jika ditinjau dari peraturan perundang-undangan tentang pengelolaan keuangan negara yang ada di Indonesia. Selain itu, penelitan mengenai penerapan best practice atas skema penerbitan catastrophe bond di Indonesia juga perlu dilakukan agar memberikan gambaran mengenai teknis pelaksanaan dan implementasinya.

Berdasarkan uraian permasalahan terkait dana penanggulangan bencana alam di Indonesia, beberapa best practice penggunaan catastrophe bond dalam pembiayaan bencana alam di beberapa negara di dunia, serta hasil penelitian terdahulu mengenai analisis rencana penerbitan catastrophe bond di Indonesia, penelitian ini bertujuan untuk menganalisis apakah catastrophe bond dapat dijadikan sebagai instrumen pembiayaan pemerintah dalam penanggulangan bencana alam di Indonesia. Hasil penelitian ini diharapkan dapat memberikan manfaat berupa solusi alternatif bagi pemerintah Indonesia dalam membiayai penanggulangan bencana alam.

\section{LANDASAN TEORI}

\subsection{Konsep Pembiayaan Risiko Bencana}

Pencegahan kerugian dan kebijakan asuransi telah lama menjadi sebuah bagian penting dalam misi perusahaan asuransi untuk memberikan perlindungan yang efektif terhadap berbagai jenis risiko (Arrow, 1963; Raviv, 1979; Gollier, 1992). Globalisasi pasar keuangan dan evolusi teknologi yang cepat telah mengubah sifat dan dampak berbagai risiko selama dua dekade terakhir. Perubahan-perubahan tersebut juga berdampak pada struktur kontrak, bentuk organisasi, dan restrukturisasi perusahaan asuransi (Doherty \& Dionne, 1993; Staikouras, 2006).

Perusahaan asuransi memperoleh modal yang sumber utamanya adalah ekuitas dan premi dari polis asuransi. Ketika memilih bentuk pembiayaan risiko, perusahaan asuransi bertujuan untuk meminimalkan risiko yang tidak didanai yang disebut sebagai defisit surplus pemegang polis (Mutenga \& Staikouras, 2004). Perusahaan asuransi sangat sulit untuk memastikan tingkat kerugian aktual dalam satu tahun buku meskipun premi yang ditetapkan telah dihitung berdasarkan berbagai skenario.

Menurut Mutenga \& Staikouras (2007), ada tiga basis instrumen pembiayaan risiko yaitu berbasis retensi, berbasis reasuransi, dan berbasis pasar modal. Tiap basis instrumen pembiayaan risiko harus sesuai dengan peruntukannya dalam distribusi kerugian. Instrumen pembiayaan risiko berbasis retensi menggunakan ekuitas yang 
disediakan oleh pemegang saham dan akumulasi laba ditahan. Instrumen pembiayaan berbasis retensi akan efisien digunakan untuk membiayai risiko dengan tingkat probabilitas kejadian yang tinggi. Sementara itu, instrumen pembiayaan risiko berbasis reasuransi dapat digunakan untuk memberikan perlindungan terhadap arus kas terkait kerugian yang tak terduga. Distribusi kerugian paling baik dibiayai oleh instrumen berbasis pasar modal. Instrumen pembiayaan berbasis pasar modal dapat mengurangi tekanan pada modal dan/atau digunakan setelah peristiwa bencana.

Keterbatasan sumber daya untuk memberikan perlindungan atas kejadian-kejadian ekstrem dalam bisnis asuransi telah mendorong para pelaku pasar untuk mengeksplorasi cara alternatif terkait pembiayaan risiko (Jaffee \& Russell, 1997; Punter, 2000; Cummins et al., 2002). Saat ini pasar modal telah memberikan wadah untuk melindungi risiko keuangan sekaligus meningkatkan nilai perusahaan (Swiss Re, 2001). Salah satu wadah tersebut yang telah menjadi sangat populer diterbitkan oleh perusahaan asuransi maupun reasuransi adalah catastrophe bond (Mutenga \& Staikouras, 2007).

Menurut Cox \& Pedersen (2000), catastrophe bond sama halnya dengan obligasi biasa. Obligasi sendiri memiliki arti surat utang jangka menengahpanjang yang dapat dipindah tangankan, yang berisi janji dari pihak yang menerbitkan untuk membayar imbalan berupa bunga atau kupon pada periode tertentu dan melunasi pokok utang pada waktu yang telah ditentukan kepada pihak pembeli obligasi. Dengan demikian, catastrophe bond dapat diartikan sebagai surat utang yang menggunakan faktor risiko bencana alam dalam kontraknya.

Menurut Hardle \& Carbrera (2007), catastrophe bond adalah obligasi yang kupon dan pembayaran pokoknya tergantung pada kinerja indeks risiko bencana alam atau terjadinya kondisi pemicu yang ditentukan. Catastrophe bond melindungi perusahaan sponsor dari kerugian finansial yang disebabkan oleh bencana alam besar dengan menawarkan alternatif atau melengkapi reasuransi tradisional.

Menurut Michel-Kerjan (2011), catastrophe bond adalah obligasi yang terikat kontinjensi multitahun yang membayar penerbitnya hanya jika terjadi peristiwa atau pemicu yang telah ditentukan sebelumnya. Pemicu bisa merupakan sebuah peristiwa eksternal (misalnya gempa bumi dengan magnitudo 8 skala richter atau di atasnya) atau berdasarkan kerugian penerbit (ganti rugi).

\subsection{Skema Penerbitan Catastrophe Bond}

Skema penerbitan catastrophe bond menurut Pollner (2001) dapat dilihat pada Gambar 1. Dana penanggulangan bencana dapat dimiliki dan dikelola secara privat atau publik. Di pasar sektor privat internasional, pengelola biasanya berbentuk Special Purpose Vehicle (SPV). SPV merupakan suatu badan hukum atau lembaga keuangan yang berfungsi untuk menginvestasikan hasil yang diperoleh dari catastrophe bond dan membayarkan kupon obligasi kepada investor. Jika terjadi bencana, dana akan dibayarkan kepada penerima yang tertanggung. Akun defeasance digunakan untuk mengakumulasi dana untuk pelunasan pokok obligasi jika investor harus menerima beberapa tingkat perlindungan utama dalam suatu peristiwa bencana. Dana yang terkumpul biasanya melebihi jumlah yang dibutuhkan untuk ganti rugi karena beberapa dana disisihkan hanya untuk pembayaran kembali pokok obligasi. Namun, beberapa obligasi disusun sedemikian rupa sehingga investor kehilangan sebagian atau seluruh pokok dan bunga jika terjadi bencana. Kompensasi dari hal tersebut adalah obligasi memberikan jumlah pengembalian jauh di atas tingkat bunga pasar untuk risiko standar yang serupa.

\section{Gambar 1. Skema Penerbitan Catastrophe Bond menurut Pollner (2001)}

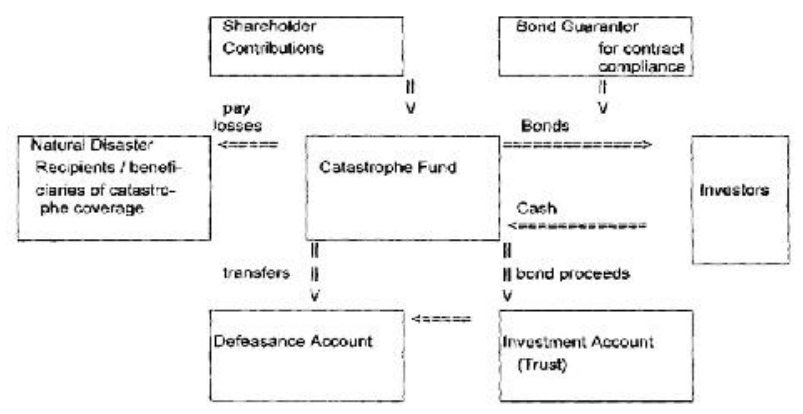

Sumber: Pollner (2001)

Adapun skema penerbitan catastrophe bond menurut Carayannopoulos \& Perez (2015) bisa dilihat pada Gambar 2. Gambar 2 menunjukkan struktur khas dari catastrophe bond. SPV berfungsi sebagai perantara antara penanggung (insurer) atau reasuradur (reinsurer) dan investor serta memfasilitasi proses penerbitan obligasi. SPV juga mengawasi pembuatan dan pengelolaan trustee (collateral account) yang menjadi muara semua aliran dana. Seringkali, kehadiran TRS Counterparty memberikan jaminan tambahan sehubungan dengan nilai jaminan dan pengembalian investasi kepada investor. Bunga dan/atau penerimaan pokok investor bergantung pada terjadinya peristiwa bencana. Nilai bunga didasarkan pada London Interbank Offered Rate (LIBOR) ditambah dengan premi. 


\section{Gambar 2. Skema Penerbitan Catastrophe Bond menurut Carayannopoulos \& Perez} (2015)

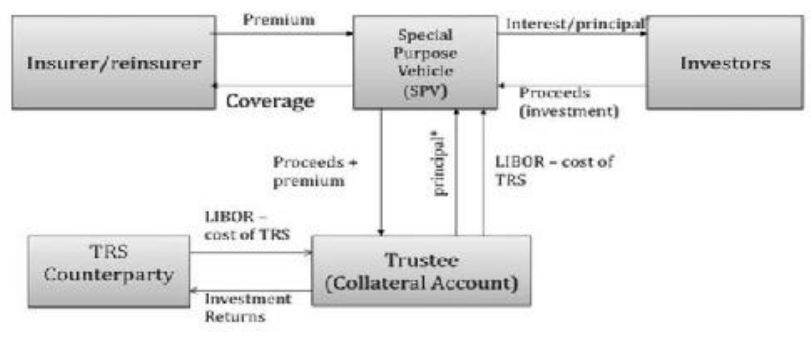

Sumber: Carayannopoulos \& Perez (2015)

Menurut Hardle \& Carbrera (2007), skema transaksi catastrophe bond melibatkan empat pihak yaitu pihak sponsor atau perusahaan ceding (perwakilan pemerintah, perusahaan asuransi, atau perusahaan reasuransi), SPV atau penerbit, pihak yang memberikan jaminan, dan investor (investor institusional, perusahaan asuransi, perusahaan reasuransi, dan perusahaan lindung nilai). Pihak sponsor mendirikan dan menetapkan SPV sebagai penerbit obligasi dan sumber perlindungan reasuransi. Penerbit menjual obligasi kepada investor pasar modal dan hasilnya disimpan dalam akun jaminan (collateral account) yang menjadi tempat pendapatan dari aset dikumpulkan dan menjadi sumber tingkat bunga mengambang (floating rate) yang dibayarkan ke SPV. Pihak sponsor membuat kontrak reasuransi atau derivatif dengan penerbit dan membayar premi. SPV biasanya memberikan pembayaran bunga kupon triwulanan kepada investor. Premi dan hasil investasi dari obligasi yang SPV terima dari pemberi jaminan adalah sumber bunga atau kupon yang dibayarkan kepada investor. Jika tidak ada peristiwa pemicu selama umur obligasi, SPV memberikan kembali pokok obligasi kepada investor dengan kupon terakhir atau bunga yang besar. Selain itu, SPV juga bisa membayar pihak sponsor sesuai dengan ketentuan kontrak reasuransi dan kadang tidak membayar apa pun atau membayar hanya sebagian pokok dan bunga kepada para investor. Skema catastrophe bond menurut Hardle \& Carbrera (2007) bisa dilihat pada Gambar 3.

\section{Gambar 3. Skema Penerbitan Catastrophe Bond menurut Hardle \& Carbrera (2007)}

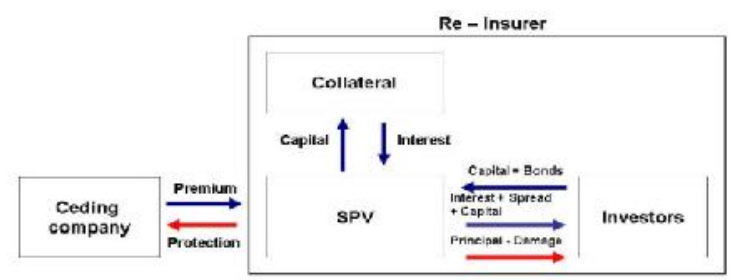

Sumber: Hardle \& Carbrera (2007)

\subsection{Teori Pecking Order}

Konsep teori pecking order pertama kali diuraikan oleh Donaldson (1961) yang mengemukakan bahwa perusahaan cenderung mengutamakan atau mendahulukan pembiayaan dari sumber internal untuk membayar dividen dan membiayai investasi. Apabila kebutuhan dana tidak mencukupi, dana dari sumber eksternal digunakan sebagai tambahan. Pembiayaan internal diperoleh dari sisa laba atau laba ditahan dan arus kas dari depresiasi. Sementara itu, pembiayaan eksternal lebih mengutamakan penerbitan utang (obligasi) daripada penerbitan saham baru. Donaldson (1961) juga menyatakan bahwa penerbitan utang (obligasi) dilakukan oleh perusahaan untuk menghindari atau mengeliminasi biaya penerbitan (flotation cost) yang melekat pada pendanaan eksternal. Penerbitan obligasi lebih dipilih dibandingkan dengan penerbitan saham baru karena flotation cost yang lebih rendah.

Myers \& Majluf (1984) mengembangkan teori pecking order sebagai suatu teori alternatif mengenai keputusan pembiayaan perusahaan. Perusahaan akan melakukan pembiayaan berdasarkan urutan risiko. Ada tiga sumber pembiayaan perusahaan yaitu, laba ditahan, utang, dan ekuitas. Bagi para investor, ekuitas lebih berisiko dibandingkan utang. Oleh karena itu, investor akan mengharapkan tingkat pengembalian yang lebih tinggi atas penerbitan ekuitas dibandingkan utang. Bagi perusahaan, laba ditahan merupakan sumber pembiayaan yang lebih baik dibandingkan utang dan utang merupakan sumber pembiayaan yang lebih baik dibandingkan ekuitas.

Teori pecking order menggunakan dasar pemikiran bahwa tidak ada target tertentu untuk debt to equity ratio. Teori ini menjelaskan hierarki sumber dana yang paling disenangi oleh perusahaan. Esensi teori ini adalah adanya dua jenis modal yaitu external financing dan internal financing. Teori ini menjelaskan mengapa perusahaan yang profitable pada umumnya menggunakan utang dalam jumlah yang sedikit. Hal tersebut bukan disebabkan oleh target debt ratio yang rendah yang telah ditetapkan oleh perusahaan, melainkan karena perusahaan memerlukan external financing yang sedikit. Perusahaan yang kurang profitable akan cenderung menggunakan utang yang lebih besar karena dua alasan yaitu, dana internal tidak mencukupi dan utang merupakan sumber eksternal yang lebih disukai.

Secara spesifik, perusahaan mempunyai urutan preferensi dalam penggunaan pembiayaan. Smart et al. (2004) menjelaskan skenario urutan dalam teori pecking order dalam empat tahap. Pertama, perusahaan lebih memilih menggunakan sumber pembiayaan internal berupa laba ditahan 
yang dihasilkan dari kegiatan operasional perusahaan. Kedua, jika pembiayaan eksternal diperlukan, perusahaan akan memilih sekuritas mulai dari yang paling aman yaitu, utang risiko rendah, utang yang lebih berisiko, sekuritas hybrid seperti convertible bond, saham preferen, dan yang terakhir saham biasa. Ketiga, perusahaan menetapkan kebijakan pembayaran dividen yang konstan tanpa mempertimbangkan laba atau rugi perusahaan. Keempat, untuk mengantisipasi kekurangan persediaan kas karena adanya kebijakan dividen yang konstan, fluktuasi tingkat keuntungan, dan kesempatan investasi, perusahaan akan mengambil portofolio investasi jangka pendek yang tersedia.

\section{METODOLOGI PENELITIAN}

Penelitan ini menggunakan metode kualitatif dengan penggunaan literatur untuk membahas hasil penelitian. Literatur-literatur terdahulu digunakan untuk menjadi latar belakang penelitian yang dilakukan dan dibuat sebelum penelitian tersebut dilakukan (Strauss \& Corbin, 1989). Selain itu, penggunaan literatur memiliki tujuan untuk membandingkan dan menyatukan hasil-hasil temuan dari penelitian yang dilakukan dengan hasil-hasil temuan dari literatur-literatur terdahulu (Burns \& Groove, 1993). Objek dari penelitian ini adalah rencana penerbitan catastrophe bond di Indonesia. Data yang digunakan adalah data sekunder yang diambil dari berbagai sumber seperti peraturan perundangundangan terkait pengelolaan keuangan negara dalam penanggulangan bencana alam di Indonesia, publikasi World Bank terkait penerbitan catastrophe bond, dan jurnal-jurnal yang relevan.

\section{HASIL PENELITIAN}

Keterbatasan dana penanggulangan bencana dalam APBN yang menjadi salah satu pertimbangan untuk menerbitkan catastrophe bond sejalan dengan hasil penelitian Jaffee \& Russell (1997), Punter (2000), dan Cummins et al. (2002) yang menyatakan bahwa keterbatasan sumber daya untuk memberikan perlindungan atas kejadian-kejadian ekstrem dalam bisnis asuransi telah mendorong para pelaku pasar untuk mengeksplorasi cara alternatif terkait pembiayaan risiko. Jika dikaitkan dengan sektor publik, dalam hal ini pemerintah Indonesia, kejadian-kejadian ekstrem yang dimaksud adalah bencana alam seperti, gempa bumi, tsunami, letusan gunung berapi, kebakaran hutan, banjir bandang, dan tanah longsor, yang kerap terjadi di Indonesia. Karena adanya faktor keterbatasan sumber daya dan kejadian-kejadian ekstrem, catastrophe bond dapat dieksplorasi sebagai cara alternatif untuk membiayai risiko akibat terjadinya bencana alam di Indonesia.
Penggunaan catastrophe bond sebagai instrumen pembiayaan pemerintah yang baru dalam menanggulangi bencana alam di Indonesia juga sejalan dengan konsep pembiayaan risiko bencana pada sektor privat khususnya perusahaan asuransi dan reasuransi yang termasuk jenis instrumen pembiayaan risiko berbasis pasar modal. Penerbitan catastrophe bond dapat mentransfer risiko dalam bentuk berkurangnya tekanan pada modal pemerintah dalam hal ini pendapatan negara di APBN. Selain itu catastrophe bond dapat digunakan setelah terjadinya peristiwa bencana. (Mutenga \& Staikouras, 2007).

Pemilihan catastrophe bond sebagai instrumen pembiayaan pemerintah bukanlah merupakan pilihan yang buruk dibandingkan dengan sumber pembiayaan lainnya. Menurut teori pecking order, dalam urutan hierarki keputusan pembiayaan, utang berada di posisi kedua setelah sumber internal (Donaldson, 1961). Jika dikaitkan dengan sektor publik dalam hal ini pemerintah Indonesia, sumber internalnya adalah pendapatan negara di APBN yang berasal dari penerimaan perpajakan, penerimaan negara bukan pajak, dan hibah. Dengan terbatasnya sumber internal tersebut, menyebabkan keputusan pembiayaan pemerintah dapat memilih opsi kedua yaitu utang. Selain itu, pemilihan catastrophe bond sebagai instrumen pembiayaan pemerintah juga sejalan dengan teori pecking order yang dikembangkan oleh Myers \& Majluf (1984) yang menyatakan bahwa faktor risiko dipertimbangkan dalam melakukan pembiayaan. Dalam penerbitan catastrophe bond, risiko akan ditransfer atau dibagi (risk transfer or risk sharing). Risiko yang timbul akibat bencana alam tidak menjadi beban pemerintah dalam APBN tetapi dibagikan ke pada para investor di pasar modal.

Rencana penerbitan catastrophe bond sebagai sebuah instrumen pembiayaan pemerintah yang baru dalam penanggulangan bencana alam di Indonesia perlu memperhatikan beberapa aspek. Aspek pertama yang perlu dipertimbangkan adalah karakteristik khusus yang dimiliki catastrophe bond dan perbedaannya dengan obligasi yang sudah pernah diterbitkan oleh pemerintah. Kedua, rencana penerbitan catastrophe bond oleh pemerintah Indonesia juga harus melihat tujuan atau alasan penerbitan serta membandingkan dengan best practice yang telah dilakukan di negara-negara lain. Selain itu, skema penerbitan catastrophe bond juga perlu ditinjau dari sisi peraturan perundang-undangan terkait pengelolaan keuangan negara.

Ketentuan mengenai obligasi yang diterbitkan oleh pemerintah diatur dalam Undang-Undang Nomor 24 Tahun 2002 tentang SUN. Dalam undang-undang tersebut disebutkan bahwa SUN adalah surat berharga yang berupa surat 
pengakuan utang dalam mata uang rupiah maupun valuta asing yang dijamin pembayaran bunga dan pokoknya oleh Negara Republik Indonesia, sesuai dengan masa berlakunya. Obligasi negara merupakan salah satu jenis SUN yang memiliki jangka waktu lebih dari dua belas bulan dengan kupon dan/atau dengan pembayaran bunga secara diskonto. Sampai di sini, obligasi negara memiliki karakteristik yang sama dengan catastrophe bond. Hal ini mendukung pendapat Cox \& Pedersen (2000) yang menyatakan bahwa catastrophe bond sama halnya dengan obligasi biasa. Karakteristik catastrophe bond yang khas adalah pihak penerbit dalam hal ini pemerintah tidak dapat menarik dana dari surat utang tersebut jika tidak terjadi bencana. Hal ini berbeda dengan obligasi negara yang dananya bisa diperoleh pemerintah setelah penerbitan obligasi. Dengan kata lain, catastrophe bond selalu menyebutkan adanya peristiwa pemicu atau faktor risiko bencana alam dalam surat kontraknya (Michel-Kerjan, 2011). Akan tetapi, meskipun tidak terjadi bencana yang merupakan peristiwa pemicu, pemerintah tetap berkewajiban membayar bunga atas catastrophe bond yang telah diterbitkan. Kewajiban membayar bunga pada setiap periode ini memiliki kesamaan dengan obligasi biasa (Cox \& Pedersen, 2000). Dengan demikian, adanya perbedaan karakteristik catastrophe bond dengan obligasi negara perlu dikaji lebih lanjut dan diakomodasi dalam peraturan perundang-undangan terkait agar bisa diimplementasikan dengan baik.

Dari aspek tujuan penerbitan, UndangUndang Nomor 24 Tahun 2002 menyatakan bahwa penerbitan SUN kepada publik merupakan salah satu potensi pembiayaan untuk mengurangi beban dan risiko keuangan bagi negara di masa mendatang. Secara lebih rinci, hal ini dijelaskan dalam Pasal 4 Undang-Undang Nomor 24 Tahun 2002 bahwa terdapat tiga tujuan penerbitan SUN yaitu untuk membiayai defisit APBN, menutup kekurangan kas jangka pendek akibat ketidaksesuaian antara arus kas penerimaan dan pengeluaran dari rekening kas negara dalam satu tahun anggaran, dan mengelola portofolio utang negara. Berbeda dengan obligasi negara yang tujuan penerbitannya untuk pembiayaan yang bersifat umum, catastrophe bond diterbitkan secara khusus untuk membiayai penanggulangan bencana. Negara Mexico yang menjadi negara pertama yang menerbitkan catastrophe bond pada tahun 2006 bertujuan untuk melindungi kewajiban fiskal terkait bencana alam (Michel-Kerjan, 2011). Begitu pula dengan negara-negara di Kepulauan Karibia yang pada tahun 2014 menerbitkan catastrophe bond dengan tujuan penanggulangan bencana angin topan dan gempa bumi (https://worldbank.org). Alasan penerbitan yang sama juga dikemukakan oleh beberapa negara di kawasan Pasifik (Chili, Kolombia, Mexico, dan
Peru) yang memutuskan untuk menggunakan catastrophe bond untuk memperluas opsi pembiayaan atas risiko gempa bumi di luar ruang lingkup dana anggaran (http://treasury.worldbank.org). Dengan demikian, secara garis besar tujuan penerbitan obligasi negara dan catastrophe bond memiliki kesamaan dalam hal pembiayaan untuk mengurangi beban dan risiko keuangan bagi negara di masa yang akan datang. Akan tetapi, tujuan penerbitan catastrophe bond yang secara khusus untuk menanggulangi bencana alam tetap perlu dituangkan dalam peraturan perundangundangan terkait agar penerbitan catastrophe bond tetap bisa dilakukan meskipun di luar tiga kondisi yang disebutkan dalam Pasal 4 Undang-Undang Nomor 24 Tahun 2002. Hal yang perlu diingat bahwa tujuan dari penerbitan catastrophe bond bukan untuk pembiayaan proyek strategis nasional melainkan untuk antisipasi.

Sebelum membahas mengenai skema penerbitan catastrophe bond di Indonesia, perlu untuk diketahui mengenai skema penerbitan obligasi negara di Indonesia berdasarkan peraturan perundang-undangan yang berlaku. Pasal 5 Undang-Undang Nomor 24 Tahun 2002 menyebutkan bahwa kewenangan menerbitkan obligasi negara berada di tangan pemerintah dan dilaksanakan oleh menteri keuangan. Sebelum menerbitkan obligasi negara, menteri keuangan terlebih dahulu berkonsultasi dengan Bank Indonesia dan harus mendapat persetujuan Dewan Perwakilan Rakyat (DPR). Pengelolaan obligasi negara di Kementerian Keuangan diselenggarakan oleh Direktorat Jenderal Pengelolaan Pembiayaan dan Risiko (DJPPR) berdasarkan Peraturan Presiden Nomor 28 Tahun 2015. Tugas DJPPR terkait dengan pengelolaan obligasi negara yaitu menyiapkan strategi dan kebijakan, penerbitan, penjualan melalui lelang dan/atau tanpa lelang, pembelian kembali, pelunasan, dan aktivitas lain dalam rangka pengembangan pasar perdana dan pasar sekunder obligasi negara. Adapun kegiatan penatausahaan obligasi negara yang mencakup pencatatan kepemilikan, kliring dan setelmen, serta agen pembayar bunga dan pokok dilaksanakan oleh Bank Indonesia. Menteri keuangan juga dapat menunjuk Bank Indonesia dan/atau pihak lain sebagai agen untuk melaksanakan pembelian dan penjualan obligasi negara di pasar sekunder. Sementara itu, kegiatan pengaturan dan pengawasan terhadap kegiatan perdagangan obligasi negara dilakukan oleh instansi pemerintah yang melakukan pengaturan dan pengawasan di bidang pasar modal.

Berdasarkan hasil studi literatur, pemerintah Indonesia dapat menggunakan skema penerbitan catastrophe bond menurut Hardle \& Carbrera (2007). Menurut Hardle \& Carbrera (2007), skema 
transaksi catastrophe bond di Indonesia dapat melibatkan empat pihak yaitu pemerintah, SPV, pihak yang memberikan jaminan, dan investor. Pemerintah dapat menetapkan SPV sebagai penerbit obligasi. Selanjutnya, SPV (BLU/BUMN) menjual obligasi kepada investor pasar modal dan hasilnya disimpan dalam akun jaminan (collateral account) yang menjadi tempat pendapatan dari aset dikumpulkan dan menjadi sumber tingkat bunga mengambang (floating rate) yang dibayarkan ke SPV. Pemerintah membuat kontrak dengan SPV dan membayar premi. SPV memberikan pembayaran bunga kupon triwulanan kepada investor. Premi dan hasil investasi dari obligasi yang SPV terima dari pemberi jaminan adalah sumber bunga atau kupon yang dibayarkan kepada investor. Jika tidak ada peristiwa pemicu (bencana) selama umur obligasi, SPV memberikan kembali pokok obligasi kepada investor dengan kupon terakhir atau bunga yang besar. Selain itu, SPV juga bisa melakukan pembayaran kepada pemerintah sesuai dengan ketentuan kontrak. SPV juga bisa saja tidak membayar apa pun atau membayar hanya sebagian pokok dan bunga kepada para investor. Skema penerbitan catastrophe bond di Indonesia menurut Hardle dan Carbrera (2007) bisa dilihat pada Gambar 4.

\section{Gambar 4. Skema Penerbitan Catastrophe Bond di Indonesia menurut Hardle \& Carbrera (2007)}

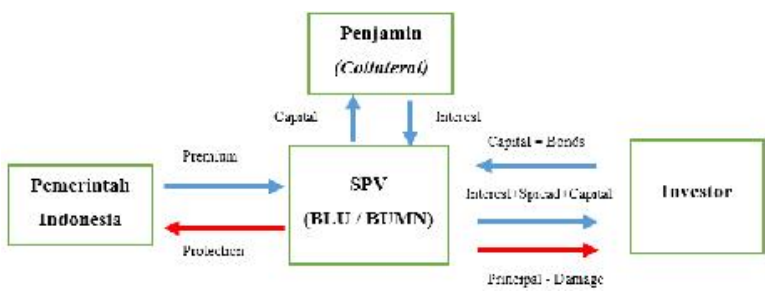

Sumber: Diolah Penulis

Secara umum, skema penerbitan obligasi negara tidak jauh berbeda dengan catastrophe bond. Keduanya melibatkan pemerintah, investor, dan penjamin atau pengawas. Hal yang membedakan dari sisi kelembagaan yaitu adanya SPV untuk penerbitan catastrophe bond. Mengingat pentingnya peran SPV dalam mekanisme penerbitan catastrophe bond, penetapan SPV perlu diakomodasi dalam regulasi. Selain itu, perbedaan juga bisa dilihat dari segi prosedur. Penerbitan catastrophe bond tidak melalui persetujuan badan legislatif karena kewenangan penerbitan berada di tangan SPV. Mengingat ketepatan waktu penyaluran dana adalah hal yang sangat krusial saat terjadi bencana, penerbitan catastrophe bond melangkahi persyaratan tersebut. Dengan demikian, perbedaan skema penerbitan antara obligasi negara dan catastrophe bond hanya terletak pada sisi kelembagaan dan prosedur. Kedua hal tersebut memerlukan penyesuaian untuk mengimplementasikan dengan baik rencana penerbitan catastrophe bond sebagai instrumen pembiayaan pemerintah dalam penanggulangan bencana alam di Indonesia.

Penetapan SPV dalam mekanisme penerbitan catastrophe bond dapat dilakukan terhadap institusi pemerintah seperti Badan Layanan Umum (BLU) atau Badan Usaha Milik Negara (BUMN) yang sudah ada. Penentuan salah satu dari dua opsi tersebut perlu mempertimbangkan beberapa hal seperti peran pengelola dana, biaya, dan manfaat atas opsi yang dipilih.

Pertama, dari aspek peran pengelola dana, baik BLU maupun BUMN dapat memenuhi kriteria ini. Berdasarkan Pasal 4 Peraturan Pemerintah (PP) Nomor 23 Tahun 2005 tentang Pengelolaan Keuangan BLU, salah satu persyaratan substantif suatu BLU adalah penyelenggaraan layanan umum yang berhubungan dengan pengelolaan dana khusus dalam rangka meningkatkan ekonomi dan/atau pelayanan kepada masyarakat. Jika dikaitkan dengan mekanisme penerbitan catastrophe bond, dana khusus tersebut adalah dana yang terkumpul dari penerbitan catastrophe bond untuk digunakan dalam penanggulangan bencana alam. Dengan demikian, BLU dapat mengambil peran SPV sebagai pengelola dana sekaligus wakil pemerintah untuk berhubungan dengan pihak terkait seperti investor dalam penerbitan catastrophe bond. Sementara itu, sesuai dengan Pasal 4 Undang-Undang Nomor 19 Tahun 2003 tentang BUMN, modal BUMN merupakan dan berasal dari kekayaan negara yang dipisahkan. Dengan kata lain, dalam menjalankan usahanya, BUMN mengelola modal atau dana dari negara untuk memberikan sumbangan bagi perkembangan perekonomian nasional pada umumnya dan penerimaan negara pada khususnya. Jika dihubungkan dengan mekanisme penerbitan catastrophe bond, BUMN juga dapat mengambil peran untuk mengelola dana yang diperoleh dari penerbitan instrumen keuangan berupa catastrophe bond untuk memberikan sumbangan penerimaan negara dalam rangka penanggulangan bencana alam nasional.

Aspek kedua yang juga perlu mendapat perhatian terkait penetapan BLU atau BUMN sebagai SPV dalam mekanisme penerbitan catastrophe bond adalah aspek biaya. Dari aspek biaya yang dikeluarkan oleh pemerintah, penetapan BLU atau BUMN yang sudah ada menjadi SPV tentu membutuhkan biaya yang lebih sedikit dibandingkan dengan mendirikan BLU atau BUMN baru.

Aspek ketiga yaitu manfaat yang diperoleh baik bagi pemerintah maupun masyarakat, BLU dapat menjadi pilihan yang lebih baik dibandingkan dengan BUMN. Sesuai dengan Pasal 
1 PP Nomor 23 Tahun 2005, BLU merupakan instansi di lingkungan pemerintah yang dibentuk untuk memberikan pelayanan kepada masyarakat tanpa mengutamakan mencari keuntungan. Dengan kata lain, melalui pemilihan BLU sebagai SPV, pemerintah dapat lebih mudah mengawasi pelaksanaan tugas terkait pengelolaan dana bencana dari penerbitan catastrophe bond karena pengelolaan keuangan BLU harus dipertanggungjawabkan kepada pemerintah dalam laporan keuangan pemerintah. Selain itu, dana yang diperoleh dari penerbitan catastrophe bond yang dikelola oleh BLU dapat lebih mudah dieksekusi atau digunakan oleh pemerintah untuk melaksanakan kegiatan tanggap darurat pada saat terjadi bencana alam. Sementara jika menggunakan BUMN sebagai SPV, pemerintah tidak dapat memiliki kontrol penuh atas pengelolaan keuangannya mengingat pelaporan keuangan BUMN dipisahkan dari pelaporan keuangan pemerintah sehingga pemerintah tidak dapat memastikan diperolehnya manfaat yang optimal. Selain itu, eksekusi dana yang diperoleh dari penerbitan catastrophe bond oleh BUMN akan menemui hambatan karena penerimaan pemerintah dari BUMN berasal dari dividen dan pajak yang proses pencairannya tidak bisa dilakukan dengan segera atau memerlukan tahap dan waktu yang cukup lama. Padahal, penanggulangan bencana alam merupakan suatu kegiatan yang bersifat darurat sehingga memerlukan dana dalam waktu sesegera mungkin. Dengan demikian, dari aspek biaya, BLU memiliki kesamaan dengan BUMN sedangkan dari aspek manfaat, BLU lebih baik daripada BUMN.

\section{KESIMPULAN DAN SARAN}

Berdasarkan hasil penelitian dan pembahasan, secara umum catastrophe bond tidak jauh berbeda dengan obligasi negara yang diterbitkan oleh pemerintah Indonesia. Perbedaan hanya terletak pada aspek karakteristik khas catastrophe bond yang terikat pada adanya peristiwa bencana, tujuan khusus penerbitan, kelembagaan, serta prosedur penerbitan. Dengan demikian, penelitian ini menyimpulkan bahwa catastrophe bond dapat dijadikan sebagai instrumen pembiayaan pemerintah dalam penanggulangan bencana alam di Indonesia.

Agar bisa mengimplementasikan rencana penerbitan catastrophe bond sebagai instrumen pembiayaan bencana alam di Indonesia, pemerintah sebaiknya terlebih dahulu melakukan revisi peraturan perundang-undangan terkait pengelolaan keuangan negara terutama mengenai penerbitan obligasi negara. Selain itu, pemerintah perlu melakukan kajian yang mendalam untuk menetapkan lembaga penerbit catastrophe bond termasuk payung hukumnya.

\section{IMPLIKASI DAN KETERBATASAN}

Penelitian ini hanya menggunakan metode kualitatif yang berfokus pada telaah pustaka atas best practice di negara lain dan membandingkannya dengan peraturan perundang-undangan di Indonesia. Penelitian selanjutnya dapat menggunakan metode kualitatif dengan mengumpulkan pendapat para ahli terkait rencana penerbitan catastrophe bond untuk penanggulangan bencana alam di Indonesia. Hasil penelitian ini memberikan implikasi berupa masukan kepada para pemangku kepentingan antara lain, DJPPR, Badan Kebijakan Fiskal (BKF), Otoritas Jasa Keuangan (OJK), Bank Indonesia, dan Badan Koordinasi Penanaman Modal (BKPM). Dengan adanya hasil penelitian ini, para pemangku kepentingan dapat dengan segera melakukan kajian mendalam dan mengimplementasikan rencana penerbitan catastrophe bond sebagai instrumen pembiayaan pemerintah dalam penanggulangan bencana alam di Indonesia.

\section{REFERENSI}

Arrow, K. J. (1963). Uncertainty and the welfare economics of medical care. American Economic Review, 53, 941-973.

Badan Kebijakan Fiskal. (2019). Strategi pembiayaan dan asuransi risiko bencana (parb). Diakses 12 Juni 2019 dari https://fiskal.kemenkeu.go.id/dw-kontenview.asp?id=20190405055846874640008

Burns, N. \& Grove, S. K. (1993). The practice of research: conduct, critique, and utilization (second edition). Philadelphia: W. B. Saunders Company.

Carayannopoulos, P. \& Perez, M. F. (2015). Diversification through catastrophe bonds: lessons from the subprime financial crisis. The Geneva Papers, 40, 1-28.

Carolina, M. (2018). Kelemahan-kelemahan penanggulangan bencana alam di Indonesia. Buletin APBN, 3 (18), 3-8.

Cox, S. H. \& Pedersen, H. W. (2000). Catastrophe risk bonds. North American Actuarial, 4 (4), 56-82.

Cummins, J. D., Doherty, N. A., \& Lo, A. (2002). Can insurers pay for the "big one"? measuring the capacity of the insurance market to respond to catastrophe losses. Journal of Banking and Finance, 26, 557-583.

DiMaggio, P. J. \& Powell, W. W. (1983). The iron cage revisited: institutional isomorphism and collective rationality in organizational fields. American Sociological Review, 48, 147-160.

Doherty, N. A. \& Dionne, G. (1993). Insurance with undiversifiable risk: contract structure and organizational form of insurance firms. Journal of Risk and Uncertainty, 6, 187-203. 
Donaldson, G. (1961). Corporate debt capacity. Cambridge, MA: Harvard University Press.

Frumklin, P. \& Galaskiewicz, J. (2004). Institutional isomorphism and public sector organizations. Journal of Public Administration and Theory, 14 (3), 283-307.

Gollier, C. (1992). Economic theory of risk exchanges in g. dionne (ed) contributions to insurance economics. Boston: Kluwer Academic Press.

Gunardi \& Setiawan, E. P. (2015). Valuation of indonesian catastrophic earthquake bonds with generalized extreme value (gev) distribution and cox-ingersoll-ross (cir) interest rate model. AIP Conference Proceedings 1692, 020024.

Hardle, W. \& Cabrera, B. L. (2007). Calibrating CAT bonds for mexican earthquakes. SFB 649 Discussion Paper, 2007-037.

Jaffee, D. \& Russell, T. (1997). Catastrophe insurance when capital is limited: a comparison of public and private approaches, Pacific Rim Insurance Conference, Singapore, 4-6 September 1997.

Kuncoro, H. (2018). Pembiayaan risiko bencana alam. Diakses pada tanggal 12 Juni 2019, dari http://harian.analisadaily.com/opini/news/ pembiayaan-risiko-bencana alam/651081/2018/11/19

Laster, D. S. (2001). Capital market innovation in the insurance industry. Sigma, 3.

Mahardika, D.P.K. (2018). Manajemen risiko melalui catastrophe bond. Diakses pada tanggal 12 Juni 2019, dari https://www.beritasatu.com/investor/5171 68-manajemen-risiko-melalui-catastrophebond.html

Mahardika, D.P.K. (2018). Manajemen risiko melalui catastrophe bond. Diakses pada tanggal 12 Juni 2019, dari https://www.merdeka.com/uang/ penerbitan-obligasi-bencana-alam-dibahasdi-pertemuan-tahunan-imf-world-bank.html

Mattuci, L. (2016). The use of catastrophe bonds as a means of economic development in emerging economies. Honors Theses and Capstones, 318.

Meyer, J. W. \& Rowan, B. (1977). Institutionalized organizations: formal structure as myth and ceremony. American Journal of Sociology, 83, 340.

Michel-Kerjan, E. O. (2011). Catastrophe financing for governments: learning from the 2009-2012 multicat program in mexico.

Mutenga, S. \& Staikouras, S. K. (2004). Insurance companies and firm wide-risk: a barrier option approach. Journal of Insurance Research and Practice, 19, 62-70.

Mutenga, S. \& Staikouras, S. K. (2007). The theory of catastrophe risk financing: a look at the instruments that might transform the insurance industry. The Geneva Papers, 32, 222-245.

Myers, S. C. \& Majluf, N. (1984). Corporate financing and investment decisions when firms have information that investors do not have. Journal of Financial Economics, 13, 187-221.

Peraturan Pemerintah Nomor 22 Tahun 2008 tentang Pendanaan dan Pengelolaan Bantuan Bencana. Jakarta: Republik Indonesia.

Peraturan Pemerintah Nomor 23 Tahun 2005 tentang Pengelolaan Keuangan Badan Layanan Umum. Jakarta: Republik Indonesia.

Peraturan Presiden Nomor 28 Tahun 2015 tentang Kementerian Keuangan. Jakarta: Republik Indonesia.

Pollner, J. D. (2001). Managing catastrophic disaster risks using alternative risk financing and pooled insurance structures. World Bank Technical Paper, 495.

Punter, A. (2000). New solutions for the financing of risk. Journal of Insurance Research and Practice, 15, 28-39.

Raviv, A. (1979). The design of an optimal insurance policy. American Economic Review, 69, 84-96.

Scott, W. R. \& Meyer, J. W. (1994). Institutional environments and organizations: structural complexity and individualism, Edited by: Scott, W. R. \& Meyer, J. W. Thousand Oaks, CA: Sage.

Scott, W. R. (2001). Institutions and Organizations (Second Edition). Thousand Oaks, CA: Sage.

Scott, W. R. (2008). Approaching adulthood: the maturing of institutional theory. Theory and Society, 37 (5), 427-442.

Shang, Q., Qin, X., \& Wang, Y. (2009). Design of catastrophe mortality bonds based on the comonotonicity theory and jump-diffusion process. International Journal of Innovative Computing, Information, and Control, 5 (4), 991-1000.

Skelley, B. D. (2000). Radical institutionalism and public administration: a review of nil's brunsson's contributions to understanding public sector organizations. Public Administration \& Management: An Interactive Journal, 5 (3), 112-122.

Smart, S. B., Megginson, \& Gitman. (2004). Corporate Finance. Ohio: South-Western, Thomson Learning.

Staikouras, S. K. (2006). Business opportunities and market realities in financial conglomerates. The Geneva Papers on Risk and Insurance - Issues and Practice, 31 (1), 124148.

Strauss, A. \& Corbin, J. (1989). Basics of Qualitative Research: Grounded Theory Procedures and Techniques. St. Louis: Mosby.

Swiss Re. (2001). Capital Market innovation in the insurance industry. Sigma, 3, 37. 
Undang-Undang Nomor 17 Tahun 2003 tentang Keuangan Negara. Jakarta: Republik Indonesia.

Undang-Undang Nomor 19 Tahun 2003 tentang Badan Usaha Milik Negara. Jakarta: Republik Indonesia.

Undang-Undang Nomor 24 Tahun 2002 tentang Surat Utang Negara. Jakarta: Republik Indonesia.

Undang-Undang Nomor 24 Tahun 2007 tentang Penanggulangan Bencana. Jakarta: Republik Indonesia. 